\title{
How to Govern Chemical Courses. The Case of the Paris École de pharmacie During Vauquelin's Direction, 1803-1829
}

\author{
Sacha Tomic
}

The Paris School of Pharmacy (École de pharmacie, hereafter the École) was established by the law of 21 Germinal year 11 (April 11, 1803). ${ }^{1}$ The new establishment succeeded the Free School (École gratuite) established on 3 Floreal year 4 (April 22, 1796), itself heir of the former Collège de pharmacie established by the reform of 1777 which separated apothecaries from grocers. This creation joined in an overall plan of education system renovation following the Revolution. Under the Consulate, pharmacists' educational fate was sealed by two chemists who held important governmental positions: the Minister of the Interior Jean Antoine Chaptal and the Council of State and General Director of Public Instruction Antoine François Fourcroy. They considered the training of the time to be too corporatist and reorganized pharmaceutical education accordingly. Henceforth, the state regulated pharmacists' training on a national scale.

The École's laboratory exemplifies a two-tiered space of chemistry and pharmacy education. Its study tackles several questions concerning governance and laboratory studies. How was the teaching of chemistry and pharmacy organized? What was the role of the laboratory's staff, including its "invisible" personnel? ${ }^{2}$ What was the moral economy at stake in this educational context? ${ }^{3}$ What was the budget and how was it managed? To what extent did the State intervene in the governance of the institution and its pedagogical guidance?

1 Two other schools were created, in Montpellier and Strasbourg. See Adolphe Trébuchet, Jurisprudence de la médecine, de la chirurgie et de la pharmacie (Paris: J.-B. Baillière, 1834). The candidates accepted into these schools became first-class pharmacists and could practice throughout France.

2 Steven Shapin, "The Invisible Technician," American Scientist 77 (1989): 554-63.

3 Lorraine Daston, "The Moral Economy of Science," Osiris 10 (1995): 2-24; French edition translated by Samuel Lézé with a presentation by Stéphane Van Damme, L'économie morale des sciences modernes (Paris: La Découverte, 2014).

(C) SACHA TOMIC, 2018 | DOI 10.1163/9789004325562_011

This is an open access chapter distributed under the terms of the CC-BY-NC License. 
In order to tackle these questions, this essay is divided into four sections. It first examines the École's administrative and pedagogical structure and discusses the specificity of the chemistry courses organized for pharmacists. The second part insists especially on the crucial role of the lab assistant (préparateur) in the implementation of experimental courses. The last two sections examine in detail the École's spending management. Section three presents the École's good governance through the evolution of its accounts and gives an estimation of the staff's salaries. The final section proposes an assessment of global annual average costs for chemistry and pharmacy courses.

Through this case study, this essay provides an example of exploiting financial sources often neglected in the historiography of science. A detailed examination of annual budgets and their correlation with bills opens new perspectives in the study of the relationships between chemistry and gover. nance.

\section{Teaching the New Chemistry to Pharmacists}

Continuity largely characterized the École's administrative and educational structure (Table 9.1). With regard to the Free School, and with the exception of Simon Morelot, a former treasurer definitively removed from the École, there was some persistence of the staff. Half of the direction (director, assistant, secretary and treasurer) was renewed, as was most of the teaching staff (full professor and his assistant) in the four chairs (chemistry, pharmacy, botany, natural and medical history or materia medica). The École also inherited the Free School's premises and facilities. This structural continuity explained the rapid implementation of reform. Soon after the publication of the Ministerial Order of 25 Thermidor year 11 (August 13, 1803) concerning pharmacy schools' organisation, the administration and professors were appointed by the governmental decree of 15 Vendémiaire year 12 (October 8, 1803). The administration had to meet at least once a month. Different assemblies could take place at professors' request and once a year the École's personnel met in a general assembly during the first days of Vendémiaire (September). ${ }^{4}$ The first assembly took place on 2 Brumaire year 12 (October 25, 1803) and the École was officially settled by a decree of 3 Frimaire year 12 (November 25, 1803) - that is, eight months after law's promulgation.

4 Archives of the Bibliothèque InterUniversitaire de Santé (BIUS), register $\mathrm{n}^{\circ} 25$, records of the assemblies from October 1803 until May 1811. 
TABLE 9.1 The École's directors and the professors of chemistry and pharmacy.

Direction Chair of Chemistry Chair of Pharmacy

\begin{tabular}{lll}
\hline Director: Vauquelin & Full professor: & Full professor: \\
Assistant director: & Bouillon-Lagrange [1803-1829] & Brongniart [1803-1804] \\
Trusson $\left[1803^{-1811}\right]$ & & Nachet [1804-1832] \\
Laugier $[1811-1829]$ & &
\end{tabular}

Treasurer:

Assistant professor:

Assistant professor:

Chéradame [1803-1824]

Henry père [1803-1826]

Bouriat [1803-1832]

Robiquet [1824-1840]

Bussy [1826-1830]

Secretary: Bouillon-

Lagrange [1803-1830]

The law of 1803 did not impose a specific program but recommended chemistry teaching which was "more specially applicable to pharmaceutical science" (Title II, art. 11). How was this institutional call for a pharmaceutical chemistry put into practice? This question raises the further question of the place of pharmaceutical practice and chemical theory in the curriculum. Lavoisierian chemistry and its training model (theory before practice), which official chemists largely adopted, were not accepted by all pharmacists. Some of them claimed that pharmaceutical practice must precede theory. ${ }^{5}$ Although the new team subscribed to this doctrine and favored "chemical philosophy" (theory), these courses were still taught after practical coursework was completed. During the deanship of Nicolas Louis Vauquelin, pupils were admitted to attend courses only after a practical internship in a dispensary (officine). ${ }^{6}$ This educational sequence, based on the weight of tradition, distinguished the École from other establishments. At the Polytechnic School (École polytech. nique) and, to a lesser extent, at the Mining School (École des mines) and at the

5 The pharmacist Jacques-Philibert Delunel criticized the young chemist Thenard, then examiner at Polytechnic School, for praising the teaching of theory before practice, Jonathan Simon, Chemistry, Pharmacy and Revolution in France, 1777-1809 (Aldershot: Ashgate, 2005), 140-45; For the acceptance of Lavoisierian chemistry by official chemists, see Bernadette BensaudeVincent's essay in this volume.

6 Courses lasted from one to three years according to the duration of internships. Candidates with an eight year internship were allowed to take the final examination without attending courses. Assembly of Germinal 8 year 12 (March 29, 1804). Archive BIUS, register n ${ }^{\circ} 25,14 \mathrm{~b}$. 
Faculty of Medicine (Faculté de médecine), pupils experimented after the lecture. ${ }^{7}$ The École would eventually follow the same path by creating its own "Practical School" (École pratique) in 1831 but, though gradually shortened, internships remained mandatory during the nineteenth-century.

The teaching of "chemical philosophy" was not new in pharmacists' curriculum. The novelty is rather to be found in the teaching of the new chemistry so as to explain everyday pharmaceutical operations. Discussion of courses' experimental character and its material consequences appeared in the assembly of May 12, 1808. Both Jean-Nicolas Trusson and Jean-Pierre-René Chéradame noted that "the professors of chemistry and pharmacy [thought] that the numerous experiments and operations performed during the courses resulted in a rather considerable quantity of products and results [...] but they had no suitable premises to deposit and preserve them."

The premises built in 1808 reflected the École's first collection of chemicals. It is important to notice that even if the chemistry and pharmacy courses were distinct, the administration considered these disciplines inseparable in their common material dimension. The École's lab was a typical chemico-pharmaceutical lab and its basic instruments and reagents were the same as those found in numerous pharmacy and chemical laboratories.

Students' notebooks give an idea of the chemistry taught at the École. The first chemistry course was given by Edmé-Jean-Baptiste Bouillon-Lagrange on 21 Germinal year 12 (April 21, 1804). ${ }^{9}$ Bouillon-Lagrange acquired his knowledge in chemistry at the Polytechnic School where he occupied the post of lab assistant and head of chemical works (chef des travaux chimiques). He also taught chemistry at the École centrale du Panthéon and at the Collège Henri IV. From these experiences he wrote a successful Manuel d'un cours de chimie. ${ }^{10}$ Bouillon-Lagrange was sometimes replaced by Noël-Étienne Henry père who was also appointed at the head of the Central Pharmacy of civilian hospitals (Pharmacie centrale des hôpitaux civils) in $1803 .{ }^{11}$ Henry père gave similar

The sequence theory-practice finally became widespread and would stand out as a "natural law" by the end of the nineteenth century. Sacha Tomic, "Le cadre matériel des cours de chimie dans l'enseignement supérieur à Paris au XIXe siècle," Histoire de l'éducation 130 (2011): 57-83.

8 BIUS, register $\mathrm{n}^{\circ} 25,30 \mathrm{a}$, my emphasis.

9 BIUS, Ms 26 . Notes taken by Nicolas Denis Moutillard, BIUs, register $\mathrm{n}^{\circ} 25,28 \mathrm{~b}$. The manuscript contains a series of about forty lessons of approximately five pages dispensed between April and August, 1804 . 
courses to the full professor's. ${ }^{12}$ According to his colleague Louis-Antoine Planche, Henry père "was not a brilliant professor, but his lessons were fully attended because the example was always given next to the rule. The pupils already provided with some elementary knowledge were rewarded."13

What was the content of these lessons? If, as Jonathan Simon noticed, Bouillon-Lagrange asserted the dominant position of "chemical philosophy" by resuming the classification given by his master Fourcroy in the Système des connaissances chimiques, the professor immediately indicated to his audience that "these divisions bring nothing useful for a pharmacist, I would not give more ample details."14 Bouillon-Lagrange adopted a mixed plan alternating general considerations and particular cases proceeding from simple to complex, following Lavoisier's pedagogical progression. ${ }^{15}$ His lessons may be divided into three parts. In the first part he defined the main notions of chemical philosophy (analysis, attraction, aggregation, caloric, elastic fluids) and reviewed the elements (oxygen, nitrogen, carbon, phosphor, sulfur, metals). Then he considered oxides and the physical properties of liquids and water. The second and longest part was dedicated to inorganic chemistry (acids, earths, alkalis, salts, metals and mineral waters). The last and shortest part dealt with vegetable chemistry (acids, immediate materials: sugar, oil, and ether) and animal chemistry (prussic acid, bile, urine).

Bouillon-Lagrange's courses did not differ fundamentally from the structure of his book, from which he borrowed some passages. However, his courses contrasted with those clearly more exhaustive ones given by Thenard at the Collège de France. ${ }^{16}$ The difference lies in the selection made by Bouillon-Lagrange to give to future pharmacists an overview of chemistry's potential to explain and improve pharmaceutical operations. The professor focused on useful compounds for pharmacy, such as arsenic, and antimony for metals, as well as camphoric acid and phosphoric ether for plant chemistry. He also addressed

12 BIUS, Ms 27 and Ms 33; BIUS, register $\mathrm{n}^{\circ}$ 25, 23b; BIUS, Ms 26, 113-15.

13 Louis-Antoine Planche, "Nécrologie sur Noël-Étienne Henry," Journal de Pharmacie 18 (1832): 522.

Système des connaissances chimiques (Paris: Baudoin, 1800-1801); Simon, Chemistry, Pharmacy, pp. 140-45, 159-60 (see note 5).

This point marks the differences in the teaching of Bouillon-Lagrange from Berthollet at the École normale, see Bernadette Bensaude-Vincent's essay in this volume. ria medica Nicolas-Jean-Baptiste-Gaston Guibourt. José Ramón Bertomeu-Sánchez, Antonio García Belmar, "Les cahiers d'élèves sources pour une histoire des contenus et des pratiques de l'enseignement de la chimie," 2004, <http://rhe.ish-lyon.cnrs.fr/cours_ magistral/expose_thenard/expose_thenard_complet.php> (accessed 29 September 2017). 
practical subjects such as "lutes" (to assure the joint and waterproofing of devices) and capillaries. The lessons did not contain pharmaceutical recipes, but the professor handled themes of interest to pharmacists, such as vegetable and animal physiology. Directly inspired by his master Fourcroy, he taught a chemistry which did not totally break with natural history. The experimental nature of chemistry courses and the choice of subjects close to pharmacists' interests seem to have answered the government's desire for a chemistry "applicable" to pharmacy, a renewed pharmaceutical chemistry. ${ }^{17}$

Pharmacy teaching was entrusted to Antoine Brongniart, but he died on February 24, 1804. Louis-Isidore Nachet succeeded him. ${ }^{18}$ Nachet had more the profile of a pharmacist than his colleague because he operated a pharmacy for fifteen years, compared to the two years of Bouillon-Lagrange. According to his biographer, Nachet was "barely assisted by his assistant Bouriat during twentyeight years of what should have been their collaboration, Nachet carried the entire weight of teaching alone."19 According to his former apprentice, the doctor botanist François-Victor Mérat, Nachet was a "deserving professor." ${ }^{20}$ Mérat informs us of the practical nature of his courses:

[Nachet was] a quite practical man, rather than a scholar, a man of the laboratory, as we say in professional terms: so the pupils looked with greediness for the details which he gave them on the particular processes in the preparation of certain medicines which were not described in books, and which pass, in a way by tradition, from laboratory to laboratory $[. .$.$] He thus trained good pharmacistsand good chemist-manipulators$ (chimistes-manipulateurs), who are the most useful, if not the most brilliant. ${ }^{21}$

Chemistry teaching and the art of chemical manipulation through pharmacy's lessons aimed more at inculcating the "new" chemistry from a practical stand-

17 This specialization of chemistry teaching was strongly supported by Bussy in $185^{\circ}$ to defend the École's chair of chemistry, archives BIUs, box n ${ }^{\circ} 312$, folder 312-8. Patrick Bourrinet, "Nachet (Louis-Isidore) 1757-1832," Revue d'Histoire de la Pharmacie 93 (2005): 301. Georges Dillemann, "Louis Isidore Nachet, $2^{\mathrm{e}}$ titulaire de la chaire de Pharmacie," Produits et problèmes pharmaceutiques 25 (1970): 1125-26.

20 François-Victor Mérat, "Notice nécrologique sur M. Nachet, professeur à l'École de pharmacie," Journal de pharmacie 18 (1832): 588.

21 François-Victor Mérat, “Nachet (Louis-Isidore)," Louis-Gabriel Michaud, dir., Biographie universelle, ancienne et moderne. Supplément (Paris, 1844), 75, 61-2. 
point to an audience already well versed in practice. ${ }^{22}$ The École also trained pharmacists who were more attracted by an effective practice of their future work, along with pupils seeking to become 'useful' chemist-manipulators. This last group would enlarge the contingent of future experts in chemical analysis and technicians needed by the growing chemical and pharmaceutical industry. Amongst the nearly 800 students trained under Vauquelin's deanship, an elite of first-class pharmacists adopted the self-proclaimed title of "pharmacist-chemist" so as to underline the profession's learned character. ${ }^{23}$ This generation became famous for numerous discoveries in chemistry and for its members' expertise as requested by the emergent regulation of industrial society. ${ }^{24}$

As this description shows, assistants were not crucial in the teaching of chemistry and pharmacy. By contrast, lab assistants were strongly implicated in the implementation of courses.

\section{The Central Position of the Lab Assistant}

Prior to the revolution, chemistry courses in France were taught by a professor (a trained physician), with the assistance of a 'demonstrator' (an apothecary) who carried out the experimental demonstrations. ${ }^{25}$ This division of labor

22 Another example illustrates this practical orientation of the École's courses. At the government's request during the assembly of April 8, 1811, Nicolas Appert was authorized to open a course "for the distribution of its process concerning the preservation of plant and animal foodstuffs." BIUS, register $\mathrm{n}^{\circ} 77$, document $\mathrm{n}^{\circ} 39-40$; register $\mathrm{n}^{\circ} 25,37 \mathrm{~b}$.

23 The average annual number of pupils (about forty) was stable until 1817 , after which it rose to a peak of 180 pupils in 1826 . By 1830 , we can estimate the population of pharmacists at approximately 10,000 for France. Their number in Paris increased from c. 100 in 1800 to c. 300 in 1830 .

24 Sacha Tomic, "Status and Role of French Pharmacist-Chemists in the History of Chemistry in the Early Nineteenth Century," paper presented at Leuven (Irish College) on June 1, 2013, workshop Situating Material and Knowledge Production in the History of Chemistry: Sites and Networks of Discipline Formation and Industrial Practice, 1760-1840. The results accumulated in a few decades by these analysts contributed to the emergence of a new speciality: organic chemistry. Sacha Tomic, Aux origines de la chimie organique. Méthodes et pratiques des pharmaciens et des chimistes (1785-1835) (Rennes: PUR, 2010). For the connection of the first industrial regulation law (decree of October 15, 1810) with environmental history, industrial chemistry, and pharmacists experts, see Thomas Le Roux, Le laboratoire des pollutions industrielles. Paris, 1770-1830 (Paris: Albin Michel, 2011).

25 Christine Lehman, "Les multiples facettes des cours de chimie en France au milieu du XVIII e siècle," Histoire de l'éducation 130 (2011): 31-56; John Perkins, "Chemistry Courses, the 
continued following the establishment of the École out of educational necessity rather than as a statutory requirement. According to the director of the École, Gustave Planchon, it was on the wishes of Nicolas Deyeux, professor of chemistry at the Free School, that the first "official lab assistant attached to chemistry courses" was appointed in April-May, $1793 \cdot{ }^{26}$ The importance of lab assistants - as demonstrators were now called - was thus underlined for teaching experimental chemistry effectively. A pharmacist's diploma was not required for the post. The lab assistant was chosen from among the "rather intelligent pupils" and he was awarded fees. Four successive lab assistants served at the École under Vauquelin's deanship: Henri-Auguste Vogel, Émile Sureau, Alexandre Bussy and Louis-Dominique Guiart fils. Vogel and Bussy were particularly active.

After apprenticeships in different pharmacies in Hanover and Brême, Vogel came to Paris in 1802 and was appointed lab assistant on 8 Germinal year 12 (March 29, 1804). Far from being limited by a position that institutionalized the division between mind and hand, he also taught chemistry at the Lycée Napoléon before he left Paris in 1816 for the chair of chemistry at the University of Munich. During his stay at the École, Vogel published some ten articles, alone or in association with Bouillon-Lagrange or Joseph Pelletier, mainly on the chemical analysis of different substances taken from materia medica (saffron, scammony, juice of buckthorn, red coral, and bitter almonds, and so on). In 1804 , he received a 400 francs fee and additional 100 francs with the condition that he "correctly carries out the duty of his place." Vogel did not disappoint the administrators who hired him. He entered the first graduation class of the École and received the gold medal at the École's first annual student competition in chemistry. The session was chaired by Fourcroy and took place on a symbolic day, the first year of Napoleon's reign (4th complementary day year 12 - September 21, 1804). Vogel became a pharmacist in 1808 and was soon promoted in 1809 with more duties and a pay raise. His position thus covered courses for chemistry, pharmacy, materia medica and, occasionally, botany. ${ }^{27}$

Bussy's career embodied the ascent of a pharmacist who rose through all the pedagogical ranks of the École. Appointed lab assistant in 1821, he became assistant professor in 1826, full professor in 1830 and finally managed the École for thirty years from 1844. After publishing on discoloration by animal charcoal

Parisian Chemical World and the Chemical Revolution, 1770-179o," Ambix 57 (2010): 27-47.

26 Gustave Planchon, L'enseignement des sciences physico-chimiques au Jardin des apothicaires et à l'École de pharmacie de Paris (Paris: Ernst Flammarion, 1897), 36.

27 BIUS, register $\mathrm{n}^{\circ} 25,34 \mathrm{~b}$. The professor of the botanical chair was also assisted by the gardener named Puyhatier dit Périgord, BIUS, register $\mathrm{n}^{\circ} 25,15$ a. 
and the first elementary analysis of morphine in 1822 , he was quickly noticed by his colleagues. In 1823, he was granted an exceptional 600 francs compensation, identical to those of professors' assistants, "for purchase of utensils and ingredients necessary for the preparation of chemistry and pharmacy courses." 28 The deliberation of August 23, 1823 signed by the secretary Bouillon-Lagrange specified the reasons for this bonus: Bussy, "having been in charge of an extraordinary work, both for the various cabinets' arrangement and chemical research, as well as the various operations, deserved to be helped."29

Bussy's last two years as lab assistant were productive. He supported Bouillon-Lagrange in 1825 instead of Henry père, a responsibility for which he received another 600 francs compensation. The following year he replaced Henry père who decided to dedicate all his energy to his function as chief-pharmacist of the Central Pharmacy of civilian hospitals. Also in 1825, Bussy began research with Louis-René Lecanu on the distillation of fats and acids which Michel-Eugène Chevreul had discovered the wet way, establishing the base for a renewed proximate analysis. Together with Dumas at the Athenée in the same year, Bussy introduced Félix-Polydore Boullay fils during chemistry courses where, according to Chevallier, he performed "practiced chemical manipulations in the École's laboratory."30 A "skilfull and recognizable manipulator," Bussy adapted the technical part of Michael Faraday's Chemical Manipulations (1827). ${ }^{31}$ He justified the necessity of such a work intended for beginners, arguing that France possessed "very few skilful workers, whereas it counts scholars in large numbers." 32

Moving down the administrative hierarchy, we notice that other people were involved in the activities of the laboratory. In a letter of 1823, BouillonLagrange specified that Bussy "was helped", which supposes that there was a kind of second lab assistant. Besides Boullay fils, who assisted Bussy, Planchon reported that Joseph-Bienaîmé Caventou was "lab assistant, for free, to the assistant of chemistry courses." ${ }^{33}$ The lab assistant also had his own assistant.

$28 A N, \mathrm{~F} / 17 / 2326$, Acounts for 1823 , first article for courses' expenses.

29 BIUS, box BLII, folder 205, extract from the École register of deliberation from August 23, 1823 .

$30 \quad$ Alphonse Chevallier, "Nécrologie de Félix Polydore Boullay (1806-1835)," Journal de chimie médicale 1 (1835): 390.

Alfred Velpeau, review of "Manipulations chimiques," Archives générales de médecine 6 (1828): 155-6; William B. Jensen, "Michael Faraday and the Art and Science of Chemical Manipulation," Bulletin for the History of Chemistry 11 (1991): 65-75. 
The École's office boy (garçon de bureau), Louis Bouré, participated in several courses, his task defined in the session of 20 Floreal year 12 (May 10, 1804). Besides the duties of office and sweeping the premises, he was "also in charge of cleaning the laboratory, its vessels and utensils," becoming then a lab boy. ${ }^{34}$ The accounts indicated that he made diverse purchases such as eggs and glue (used for "lutes"), washed the laboratory cloths (used for filtrations), and supplied coal for furnaces and heating.

Through these different activities, it appears that the laboratory was also a place of research where the École's entire staff participated in its educational activities. The courses took place only during the summer semester (1st Germinal to 1st Fructidor - March 22 to August 19), which left the winter semester (from September to March) for examinations and for the staff's own use. Bouillon-Lagrange, who had been without his own pharmacy since 1789 , performed at least some of his experiments at the École, as did Vogel and Bussy. A privileged number of students also performed practical works.

To sum up, the lab assistants, assisted or not by a lab boy, did not content themselves with preparing experiments or chemicals for courses. They also performed original research and published in scientific journals and often advanced the money for and took care of the supply of equipment and chemicals. $^{35}$ They drafted "spending for the course" reports that were approved by the professor or the director.

In her seminal paper on moral economy, Loraine Daston quoted Claude Bernard and John Pond's opinions about the division of labor in science. ${ }^{36}$ For Daston, both men considered that repetitive work (observation, data collection, calculations) must be performed by "uneducated men" and "drudges". This example of "mechanical objectivity" in which uneducated lab assistants were considered as devices contrasts with the École's pedagogical organization. The valuation of scientific work highlighted by Daston as characteristic of this period, that is to say, did not necessarily hold in an educational context, especially in pharmacy where morality was one of the qualities officially

34 BIUS, register $\mathrm{n}^{\circ} 25,15 \mathrm{~b}$.

35 Those technicians who became pharmacist-chemists can be considered as hybrid-experts in the sense of Ursula Klein, "Apothecary's Shops, Laboratories and Chemical Manufacture in Eighteenth-Century Germany," Lissa Roberts, Simon Schaffer, Peter Dear, eds., The Mindful Hand. Inquiry and invention from the late Renaissance to early industrialisation (Amsterdam: Royal Netherlands Academy of Arts and Sciences, 2007), 247-276; Ursula Klein, ed., special issue on "Artisanal-scientific Experts in Eighteenth-century France and Germany," Ambix 69 (2012).

36 Daston, “The Moral Economy," p. 20 (see note 3). 
required by the profession. ${ }^{37}$ Often characterized by historians as uneducated "invisible hands", lab assistants at the École were both visible and educated laboratory managers, who actively contributed to the success of experimental chemistry teaching. ${ }^{38}$ In brief, the lab assistant was the main administrator and technician of chemical and pharmaceutical courses, who, in close collaboration with professors, contributed to the École's prestige and good governance.

\section{The École's Good Governance}

The École's accounts provide information about the moral economy and material frame of its courses. ${ }^{39}$ Two treasurers served during Vauquelin's deanship: the former Free School's assistant director Chéradame and Pierre-Jean Robiquet. ${ }^{40}$ The Ministerial Order of 25 Thermidor year 11 (August 13, 1803) concerning the École's regulation specified that the treasurer was appointed for three years, whereas the director had a five-year term; both were eligible for reelection. ${ }^{41}$ Article 10 specified that "every year, in the first days of Vendémiaire [September-October], the treasurer will report the previous year's revenues and expenditures, at the École's general assembly. This account will be checked by the prefects of the department, and in Paris by the Prefect of police. It will then be submitted for the approval of the Minister of the Interior." This administrative procedure explains why certain accounts were officially validated only one

37 Pharmacists had to take an oath in front of the Prefect to validate their diploma. The École's administrators did not hesitate to dismiss pupils for "deviant behavior" as happened to a certain Gauthier in 1806, BIUS, register $\mathrm{n}^{\circ} 25,25$-a-26b.

38 Another example of the visibility of laboratory workers is given by José Ramón BertomeuSánchez, Antonio García Belmar, "Louis Jacques Thenard's Chemistry Courses at the Collège de France, 1804-1835," Ambix 57 (2010): 48-63. These processes of visibility/invisibility are still at stake in the evolution of contemporary science. Florence Millerand, "Les gestionnaires d'information 'invisibles' dans la production d'une base de données scientifiques," Revue d'anthropologie des sciences 6 (2012): 163-19o.

It has been possible to reconstitute the various budgets thanks to the whole collection of annual accounts preserved at the Archives Nationales (series F/17/2325 and F/17/2326). Some of them have been correlated, for certain years and for certain spending, to the diverse itemized bills kept by the BIUS (box BLI, folders 1-100; box BLII, folders 101-230). Pierre Julien, "Plaidoyer pour les notes et factures anciennes de pharmacie," Revue d'histoire de la pharmacie 37 (1990): 81-92. 
or even two years after their writing. Chéradame presented his first account in the session of 6 Nivôse year 13 (December 27, 1804), signed by the professors and approved by the Prefect on 18 Brumaire year 14 (November 9, 1805). In a letter read at the assembly on 7 Frimaire year 14 (November 27, 1805), the Minister of the Interior Chaptal expressed through the Prefect his "satisfaction of the good order which reigns in the accounts [of 1804]."42 With these words, the Government paid tribute to the treasurer, emphasizing his central role in the good governance of the establishment.

A typical account is divided into revenues and expenditures, themselves divided into chapters concerning a more or less precise subject. Revenues distinguished between the previous year's surplus and three items which fed the budget: pharmacists' graduation fees (fixed at goo francs by law), by far the most important income amounting to nearly three-quarters of the revenues; visitation rights for pharmacists (six francs), druggists and herbalists (two francs); and registration fees (thirty-six francs/year). The expenditure records consisted generally of ten chapters, the most important expense items concerning renovation work. ${ }^{43}$ Settled on the same location as the Jardin des apothicaires, founded in 1626 (13 rue de l'Arbalète), the École inherited buildings of the Free School and a laboratory built in 1702 and enlarged in 1760. The primitive building (c. $\left.250 \mathrm{~m}^{2}\right)$ contained a "big laboratory for demonstrations and public courses" (c. $\left.90 \mathrm{~m}^{2}\right) \cdot{ }^{44}$ Even if the overall building configuration did not change much during Vauquelin's deanship, the École underwent perpetual remodelling during this period, both inside and outside. The garden was continually in development and different spaces were created: a laboratory for receptions (1804), an amphitheater of botany and natural history (1805), a locale for chemicals (1808), a space for mineralogy (1824) and materia medica and mineral collections (1826).

The budgetary evolution of the École's governance reveals three phases (Graph 9.1). The average expenditures were about 36,00o francs for the period 1804-1815; they increased by 30 percent during 1816-1823 (47,000 francs) and again by 46 percent to reach about 68,00o francs at the end of Vauquelin's

42 BIUS, register $\mathrm{n}^{\circ} 25,24 \mathrm{a}$.

43 Expenditure headings: 1. Examiner's rights of presence, 2. Staff fees, 3. Course expenditures, 4. Extraordinary expenditures, 5. Work expenditures, 6. Visitation fees, 7. Office fees, 8. Administrators' expenditures, 9. Gardener and lab boy expenditures, 10. Treasurer allowances.

44 BIUS, Ms 87, N.-J.-B.-G. Guibourt, "Exposé historique sur l'origine et les augmentations successives de l'immeuble affecté à l'École de Pharmacie," reproduced (without the first nine pages) in Adrien Philippe, Histoire des apothicaires (Paris: Direction de la Publicité Médicale, 1853), 253. 


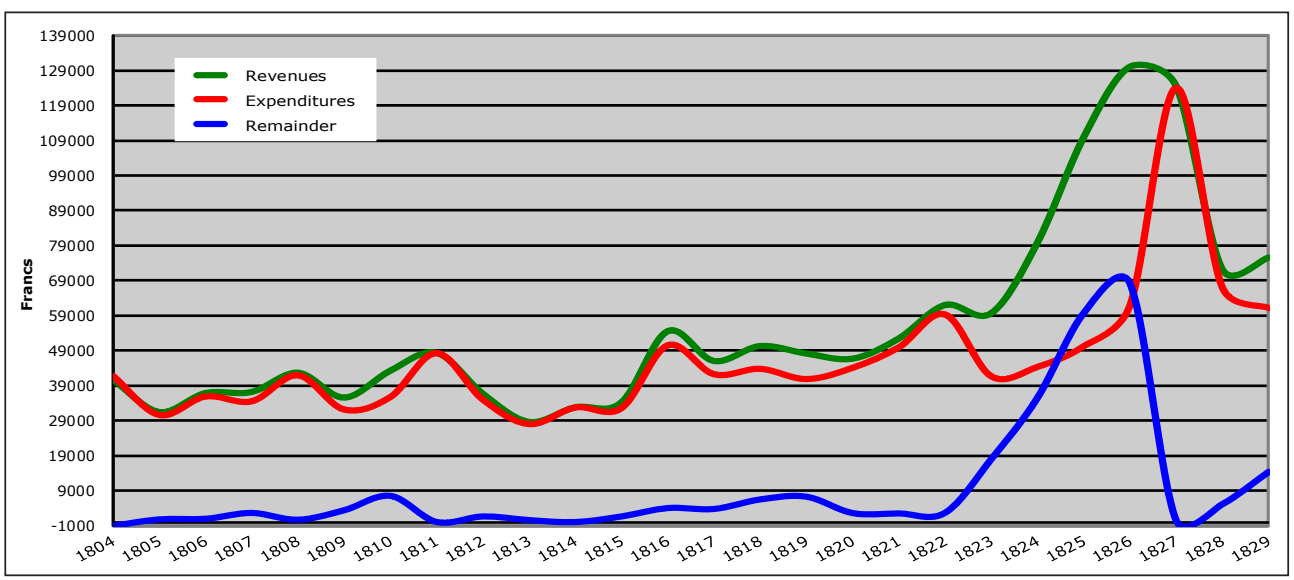

GRAPH 9.1 Evolution of the École's accounts.

deanship (1824-1829). The average revenues, following the increasing number of graduating pharmacists, became established at 37,00o francs for the first period, increased by 40 percent for the second period (53,000 francs) and jumped to 88 percent (about 100,00o francs) for the last period. For the whole period, the total average amounts were about 1.28 million francs for expenditures, and about 1.46 million francs for the revenues with a profit of about 180,000 francs. With the government's agreement, a part of the exceptional revenues accumulated in 1826 (more than 50,00o francs) was deposited in an interest-paying account.

How did this good governance apply to staff salaries? Several sources of income, divided into fixed and mobile parts, covered the staff's expenses. The fixed part did not concern the management. Professors' indemnities were fixed by the government at 1,500 francs whereas lab assistants' indemnities were decided by the École's administration and fixed at 600 francs $(750$ francs from 1823). ${ }^{45}$ Lab assistants' fixed indemnity rapidly increased, going from 500 francs in 1804 to 1,200 francs from 1812 . Salaries more than doubled (by 140 percent) in eight years, competing with those of a professor. The wages of the office-lab boy, who also received housing, increased more slowly. His income (without bonuses as New Year's gifts), passed from 500 francs in 1803 to 800 francs from

45 BIUS, box BLII, folder 205, extract from the École's register of deliberation from August 30 , 1821. As a comparison, fixed indemnities were twice as high for professors at the Faculty of Medicine (3,00o francs), more than three times at the Polytechnic School and National Museum of Natural History (5,00o francs), and four times at the Collège de France (6,00o francs). 
1819 , with a global increase of 80 percent. As we have seen in the previous section, this appreciation of salaries underlines the fundamental role of lab assistants in the laboratory management and contributed to their visibility.

The mobile part of the École's income, which represented the directors' only revenue stream, was divided into several parts which substantially increased the total income. These sums grew with the number of candidates. The institution's life was punctuated by assemblies, examinations and other public meetings for which the staff received remuneration. The "rights of presence" (droits de présence) for the examinations fixed by the law represented an important part of income. For each successfully passed examination, a sixtysix franc sum was assigned to the examiners. This income was about 1,000 $-1,500$ francs for a professor and the director, and about $500-1,500$ francs for the assistant professors and the treasurer. The administrative tasks with attendance fees to the assemblies were fixed at four francs "both for the office assemblies held by the administrators, and by the committees and the assemblies of École's members," which represented about 150 francs per professor, assistant and administrator. ${ }^{46}$ The "rights of presence" for the competitions were fixed at eight francs per session, that is twenty-four francs for three days. ${ }^{47}$ The directors received compensation for examination expenses (thirty francs / reception) which notably increased their salary. For example, in 1826, the director, his assistant and the treasurer received about 2,00o francs. From 1826 onward (revenue peak), a secondary account appeared. It concerns the budget for the last practical examination (300 francs / candidates) initiated by Bussy. ${ }^{48}$ The bulk of the income was used for compensation (twenty francs / sessions) and stood at about 1,500-2,000 francs for administrators, and 1,000-1,500 francs for professors and assistants.

Finally, we can estimate a 4,000 francs average salary for a full professor, 2,500 francs for an assistant professor, 1,00o francs for a lab assistant, and about 700 francs for the office/lab boys. As for the directors, whose members could also be appointed professor, the average income estimation is as follows: 3,5004,000 francs for the treasurer, 2,500-3,500 francs for the director, and 2,000-3,000 francs for his assistant. The salaries from the lab assistant to the professor were

46 These fees were justified during the assembly of October 4, 1806 for the reason that "the École members cannot give up their own pharmacy without receiving a compensation," BIUS, register $\mathrm{n}^{\circ} 25,27 \mathrm{~b}$.

47 At least for 1823 , BIUS, box BLI, folder 69 .

48 Alfred Riche, "Notice biographique sur Bussy," Journal de pharmacie et de chimie 5 (1882): 303. 
in a 1:4 ratio with attractive gaps so as to develop staff loyalty and encourage the personnel to climb the ladder to professorship as exemplified by Bussy.

\section{Controlling Course Expenditures}

With few exceptions (1804 and 1819), teaching expenses were grouped in annual accounts under chapter III "concerning the various purchases required for the courses of chemistry, pharmacy, natural history and other expenses relative to courses." ${ }^{\prime 9}$ Botany expenses (gardener, maintenance of the garden, plants collections) were often scattered in other account sections. To have a closer look at the specific budget concerning chemistry and pharmacy courses (materially and financially inseparable), it is necessary to estimate the amount devoted to the cabinet of natural history and materia medica. Several elements enabled the minimization of this cost. First of all, the majority of reports (mémoires and mémoires quittancés), those detailing the price of every article - often simple invoices - stipulated explicitly the "supply of objects appropriate to chemistry and pharmacy."50 The comparison of itemized bills (chemicals, vessels and utensils, instruments) with the total of courses' expenses confirms the dominating place of a budget peculiar to chemistry and pharmacy teaching. ${ }^{51}$ At the same time, most of the expenses corresponding to materia medica courses offered during different periods were included under the chapter "exceptional expenses". From 1824 onward, at the instigation of Pelletier who replaced Robiquet as chair of materia medica in 1825, the expenses remained stable and regular (approximately 2,00o francs for minerals bought between 1824 and 1829, that is an average of 333 francs/year). Materia medica expenses can be estimated to approximately 5,000 francs, or nearly 200 francs/year for 1803-1829. With regard to the average course expenses (2,180 francs), this amount represents approximately 10 percent. It was then possible to deduct an annual average cost specific to chemistry and pharmacy courses of about 2,000 francs, or 4.5 percent of total expenses (Graph 9.2). One can notice that this proportion, higher at the École's beginnings (5.5 percent from 1804 till 1817), decreased from 1812 and became stable from 1818 (3.5 percent for 1818-1829). This order of magnitude corresponds to the amount mentioned by Fourcroy in

\footnotetext{
49 Archives Nationales series $\mathrm{F} / 17 / 2325$.

$50 \quad$ Archives Nationales series F/17/2326.

$5^{1} \quad$ The BIUS archives provides bills for thirteen years (1806-1814, 1819, 1821, 1823 and 1824) i.e. $50 \%$ of the twenty-six years of Vauquelin's deanship.
} 


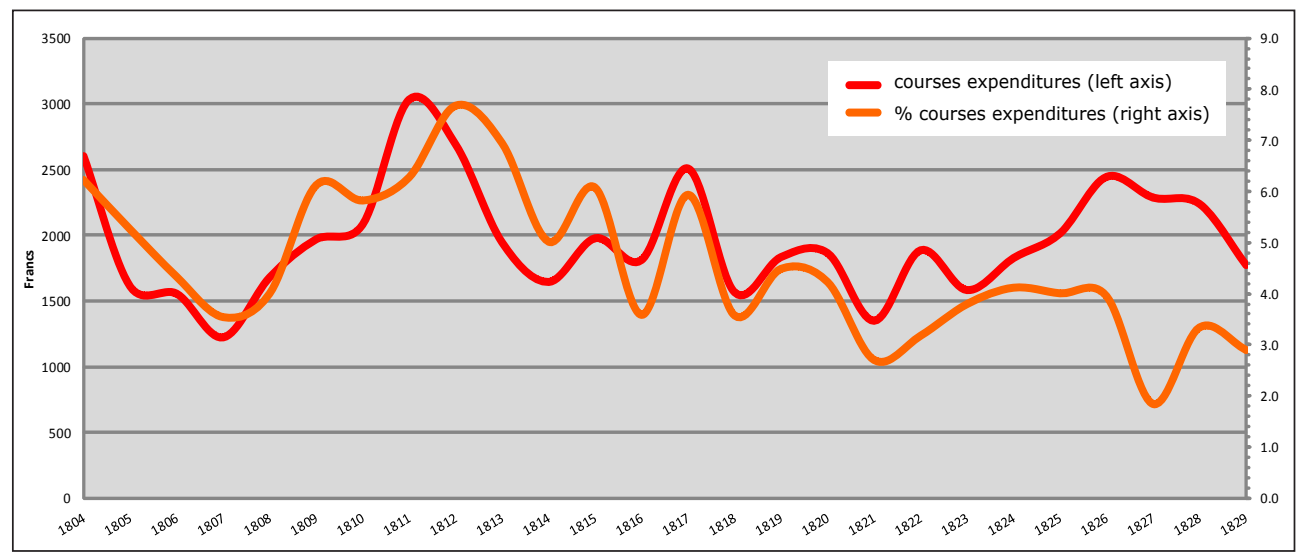

GRAPH 9.2 Evolution of the École's chemical \& pharmacy courses expenditures.

the Methodical Encyclopedia as necessary to maintain "a daily laboratory service. ${ }^{52}$

From the midpoint of Vauquelin's deanship, the number of enrolled students converged toward the number of receipts, which means that practically all students followed a "normal" education of three years. By this time, the École achieved its cruising speed and administrators succeeded in mastering chemistry and pharmacy expenses, in spite of the staff's salary increases, with income from the growing number of received pharmacists. These considerations are consistent with the administration's desire to control the École's expenses. During the session of 7 Frimaire year 14 (November 27, 1805), the directors decided that the "maximum of course expenses for 1806 [will be fixed] at 2400 francs." ${ }^{33}$ With few exceptions, this maximum was never exceeded.

The control over course-related spending was also the consequence of a faithful network of various suppliers which included some of the École's members. Pharmacist-chemists, whose name was a warranty of their products' quality, had a monopoly on the production of high value-added products. Next to a high-grade chemical industry, a market existed for teaching equipment whose development was strongly tied to pharmacists' business. ${ }^{54}$ Not sur-

\footnotetext{
$5^{2}$ A.F. Fourcroy, "Opérations," Encyclopédie méthodique - Chimie (Paris: Panckoucke, 1808), vol. 5,272 .

53 Archives Nationales series F/17/2325.

54 Anna Simmons' discussion in this volume of the formation of a marketplace (in relation to the sale of drugs in London, in her case) can be extended to the emerging education market. This market was not specific to France as the case of Friedrich Accum suggests, but further comparative studies are needed.
} 
prisingly, we find among the main chemicals suppliers, the director Vauquelin and the professors of materia medica Jacques-Paul Vallée and Robiquet. This new revenue stream (from a few thousand to 100,000 francs a year) was apparently accepted as natural and no conflict of interests was highlighted.

After a more or less chaotic financial association with various partners (Gilbert Deserres, Henry Lemercier and Hervé), Fourcroy and Vauquelin established their own business, the Manufacture de produits et de réactifs chimiques, in July 1804, which was housed at rue du Colombier, 23 (6th district) on land bought in November $1800 .{ }^{55}$ In a letter of May 18, 1807 addressed to the Italian physicist and agronomist Giovanni Fabbroni, Vauquelin indicated that he was henceforth the only owner of the factory. The director specified that "Professors, Chemists, Pharmacists, Traders and Students, can be sure from now on to find in [his] stores all the reagents in a state of perfect purity, or the preparations necessary for their demonstrations, for their trade, for their studies or for their research." ${ }^{56}$ In 1804 , the factory delivered vessels and utensils valued at more than 1000 francs under the name of Deserres and Lemercier. ${ }^{57}$ The factory also provided instruments (such as barometers, thermometers, hydrometers, instruments for mineralogy, apparatus for physics, and so on) and glassware. Vauquelin also proposed the shipping of books to clients.

In spite of its financial setbacks, the factory operated continuously thanks to the massive financial contribution of Fourcroy $(150,000$ francs) and Vauquelin $(100,000$ francs) to cope with the debts of their partner. Their associate Lemercier was mostly responsible for the bad financial situation of the factory. This commercial failure was also the consequence of the implementation of the first industrial regulation law of October 15,1810 . The factory had settled in the very heart of Paris and was the subject of periodic complaints from neighbours. ${ }^{58}$ In 1818, Lemercier chose to move the large-scale production of acids and phosphorous substances to the suburbs and the factory was sold for 88,000 francs in August, 1822 to Jean-Baptiste Quesneville who, with his son Gustave Augustin, would make it a prosperous establishment.

This episode shows that Fourcroy and Vauquelin were, at first sight, quite bad managers. This 'bad governance' was not only due to some risky financial

\footnotetext{
55 Maurice Bouvet, "Nicolas Vauquelin, droguiste," Revue d'histoire de la pharmacie 46 (1958): 246-52.

56 American Philosophical Society, Mss. B Fi13.

57 Vauquelin sold copper, crystal, glass, porcelain and stoneware "chemical and pharmaceutical” vessels; flasks filled with emery, melting pots and capsules made of platinum, silver and china.

$5^{8}$ Thomas Le Roux, Le laboratoire des pollutions, pp. 242, 305-12, 466, 484-86 (see note 24).
} 
choices. It was also the result of a proactive education policy. Fourcroy and Vauquelin's factory was a non-profit creation. ${ }^{59}$ The creation of the establishment, the first one of this kind in France, was more a political act to promote a new kind of chemical education than to build a lucrative business. Moreover, different courses took place in the amphitheater located inside the plant. Rather than seek an immediate profit, the moral economy at stake behind the factory's owners was to promote a model for experimental chemical education and to support the École's good governance.

Unlike Vauquelin, two other École suppliers, Vallée and Robiquet, sold chemicals exclusively for profit. Vallée was appointed assistant professor of materia medica in 1803 and full professor in 1811. He was the owner of a pharmacy on rue Saint-Victor, $\mathrm{n}^{\circ} 98$ (12th district) from 1802 to which he "annexed a small factory of chemicals" and supplied the École, even with living vipers. ${ }^{60}$ In his obituary, Nachet insisted on "the considerable increase of this business which began with the moderate sum of 1,200 francs." ${ }^{\prime 1}$ After his departure, Robiquet settled on the rue de la Monnaie, $n^{\circ} 9$ (1st district) and took over and supplied the majority of products from 1818. In 1826 he joined Aristide Boyveau, who possessed a factory on the rue des Fossés-SaintGermain-l'Auxerrois, $\mathrm{n}^{\circ} 5$ (1st district). Together with Pelletier they created a factory in 1834 on the rue des Francs-Bourgeois-Saint-Michel, n ${ }^{\circ} 8$ (6th district).

Other suppliers of chemicals (Table 9.2) included the pharmacist Charles Baget for phosphorus and iodine, Paul Blondeau for spring waters, the apothecary-druggist Charles Bouvier for mineral acids, the director of the Faculty of Medicine's chemical laboratory Jean-Pierre Barruel for potassium, the grocer Sureau fils for alcohol and vinegar, and the druggist Bonnes who provided mercury in 1804 (doubtless for pneumatic tanks). Different distillers regularly supplied the École with large quantities of spirits (eau-de-vie) and alcohol, one of the favorite solvents used in proximate analysis. Beside Vauquelin, the École possessed another almost official supplier of vessels and utensils, the potter and master glassmaker Jean-Baptiste Acloque, who occasionally also took care of the equipment. Different potters, oven makers, boilermakers and paper-

59 Georges Kersaint, "L'usine de Fourcroy et Vauquelin," Revue d'histoire de la pharmacie 47 (1959): 25-30; Alain Queruel, Vauquelin et son temps (1763-1829) (Paris: L'Harmattan, 1994), 116-23.

$60 \quad$ Georges Dillemann, "Jacques Paul Vallée, 1772-1814," Produits et problèmes pharmaceutiques 26 (1971): 426.

$61 \quad$ Louis-Isidore Nachet, "Nécrologie de Vallée," Journal de pharmacie 6 (1814): 38o-83. 
TABLE 9.2 The École's various suppliers of chemicals (main suppliers in bold).

\begin{tabular}{|c|c|c|c|}
\hline Suppliers & Profession & Address & Chemicals \\
\hline Vauquelin & $\begin{array}{l}\text { Professor of chemistry, Director of } \\
\text { the École }\end{array}$ & Rue du Colombier, $\mathrm{n}^{\circ} 23$ & Various \\
\hline Vallée & $\begin{array}{l}\text { Pharmacist, Professor of materia } \\
\text { medica at the École }\end{array}$ & Rue Saint-Victor, $n^{\circ} 98$ & Various \\
\hline Robiquet & $\begin{array}{l}\text { Pharmacist-chemist, Professor of } \\
\text { materia medica and treasurer at the } \\
\text { École }\end{array}$ & Rue de la Monnaie, $n^{\circ} 9$ & Various \\
\hline $\begin{array}{l}\text { Robiquet- } \\
\text { Boyveau }\end{array}$ & $\begin{array}{l}\text { Ibid } \\
\text { Industrialist }\end{array}$ & $\begin{array}{l}\text { Rue des Fossés-St-Ger- } \\
\text { main-L'Auxerrois, }{ }^{\circ} 5\end{array}$ & Various \\
\hline Baget & Pharmacist & $\begin{array}{l}\text { Rue vieille du Temple, } \\
\mathrm{n}^{\circ} 79\end{array}$ & $\begin{array}{l}\text { phosphorus, } \\
\text { iodine }\end{array}$ \\
\hline Blondeau & Pharmacist & $\begin{array}{l}\text { Rue de Condé, } \mathrm{n}^{\circ} 22 \& \\
\text { Rue de Tournon, } \mathrm{n}^{\circ} 17\end{array}$ & Spring waters \\
\hline Bouvier & Apothecary-druggist & $\begin{array}{l}\text { Rue des Vieilles-Tuilleries, } \\
\mathrm{n}^{\circ} 19\end{array}$ & Mineral acids \\
\hline Barruel & $\begin{array}{l}\text { Director of the chemical laboratory } \\
\text { at the Faculty of Medicine }\end{array}$ & $\begin{array}{l}\text { Rue de l'École de } \\
\text { Médecine }\end{array}$ & Potassium \\
\hline Sureau fils & Grocer & Rue du Bourg-l'Abbé, $n^{\circ} 4$ & $\begin{array}{l}\text { Alcohol, } \\
\text { vinegar }\end{array}$ \\
\hline Bonnes & Druggist & & Mercury \\
\hline Various & Distillers & & Spirits \\
\hline
\end{tabular}

makers supplied furnaces and other accessories, as well as providing reams of Joseph's paper and other papers used in filtrations (Table 9.3).

Instruments were supplied by "patented instruments engineers", especially Dumotiez and his successor and nephew Nicolas Constant Pixii (Table 9.4). ${ }^{62}$ They supplied generally expensive devices such as a pneumatic machine (220 francs in 1808), a device for water decomposition (120 francs in 1813), and a Volta eudiometer (40 francs in 1819). Jean-Gabriel-Augustin Chevallier said the

62 Dumotiez was one of the first to receive an "engineer's certificate in instruments of optics, physics, and mathematics" with privilege delivered in April, 1788 by the Committee of the artists of the Royal Academy of Sciences, created at the instigation of the astronomer Dominique Cassini, Mémoires pour servir à l'histoire des sciences et à celle de l'Observatoire Royal de Paris 1810 (Paris: Bleuet), 86-94. 
TABLE 9.3 The École's various suppliers of utensils (main suppliers in bold).

\begin{tabular}{|c|c|c|c|}
\hline Suppliers & Profession & Address & Utensils \\
\hline Vauquelin & $\begin{array}{l}\text { Professor of chemistry, Director of } \\
\text { the École }\end{array}$ & Rue du Colombier, $\mathrm{n}^{\circ} 23$ & Various \\
\hline Acloque & Glassmaker & Rue de la Barillerie, $\mathrm{n}^{\circ} 22$ & Various \\
\hline Blanc & Potter and oven maker (fournaliste) & Rue de Larbralètre, $\mathrm{n}^{\circ} 12$ & Furnaces \\
\hline Gaillard & Boilermaker & & Furnaces \\
\hline Petit aîné & Trader (négociant) & $\begin{array}{l}\text { Rue Saint-Jacques-la- } \\
\text { Boucherie, } \mathrm{n}^{\circ} 23 \& 25\end{array}$ & Test tubes \\
\hline Paillard & Paper-maker & & Joseph paper \\
\hline
\end{tabular}

TABLE 9.4 The École's suppliers of instruments (main suppliers in bold)

\begin{tabular}{|c|c|c|c|}
\hline Suppliers & Profession & Address & Instruments \\
\hline Dumotiez & $\begin{array}{l}\text { Patended instrument } \\
\text { engineer }\end{array}$ & Rue du Jardinet, $\mathrm{n}^{\circ} 2$ & $\begin{array}{l}\text { Pneumatic machine, air } \\
\text { thermometer, pyrometer }\end{array}$ \\
\hline Pixii & $\begin{array}{l}\text { Patended instrument } \\
\text { engineer }\end{array}$ & Rue du Jardinet, $\mathrm{n}^{\circ} 2$ & $\begin{array}{l}\text { Pneumatic machine, Volta's } \\
\text { eudiometer, galvanic devices }\end{array}$ \\
\hline $\begin{array}{l}\text { Chevallier (Le } \\
\text { Chevalier) }\end{array}$ & $\begin{array}{l}\text { Patended instrument } \\
\text { engineer }\end{array}$ & $\begin{array}{l}\text { Quai \& Tour de l'Horloge } \\
\text { du Palais, } n^{\circ}{ }_{1}\end{array}$ & $\begin{array}{l}\text { Hydrometers, Descroizille's } \\
\text { stills }\end{array}$ \\
\hline $\begin{array}{l}\text { Chemin fils and } \\
\text { Chevillé fils }\end{array}$ & $\begin{array}{l}\text { Mechanics (balan- } \\
\text { ciers-mécaniciens) }\end{array}$ & & Balances \\
\hline Dourches & Instrument maker & & Precision balance \\
\hline
\end{tabular}

engineer Chevallier (Le Chevalier), sold hydrometers and Descroizilles stills for wine assays (54 francs in 1823). The mechanics (balancier-mécanicien) Chemin fils and Chevillé fils sold and repaired balances, and Dourches provided an expensive precision balance (330 francs) in 1828.63 Some of these instrument-makers, such as Pixii, built an international reputation and provisioned universities including Leuven, Turin, Moscow, Warsaw, and Coïmbra in Europe, as well as across the Atlantic.

63 Louis Marquet describes a Fourché-Chemin balance, "Balances et boîtes de poids de la collection de la Société d'Histoire de la pharmacie," Revue d'histoire de la pharmacie 34 (1987): 41-46, see 43-4. 
In the end, and in order to promote an updated, high-quality chemical education, the good management of the École ensured a reconciliation between educational requirements and equipment. Quality reagents and instruments placed at the staff's disposal were provided by the best traders according to market prices and a policy of loyalty. Alongside this liberal management of material resources, the École's direction also promoted an attractive internal promotion policy based on a moral economy that provided its reputation and identity.

\section{Conclusion}

This essay ends as the École, supervised by the new director André Laugier, was about to enter a new phase. Thanks to the surplus of the previous years, the École added two new wings. Under the impulse of Bussy, a Practical School was created in 1831 . This paid training addressed pupils duly selected by competition and constituted, after the Polytechnic School in its early stages, the first regular training of practical chemistry within higher education. The administration was to confirm and endow this training with a specific budget during the École's affiliation with the University by the ordinance of September $27,1840 .{ }^{64}$

Despite State control, the École kept a large degree of autonomy. This was especially true for the training program but also for the École's management. Its good governance rested on financial management but also on the sharing of common values. Administrators and professors established a moral economy founded on a compensation policy for the staff, on promotion of moral and scientific "excellence" amongst students and lab assistants, and on the adaptation of chemistry courses intended for the profession. The promotion from lab assistant to professor as embodied by Bussy in this essay, was not specific to pharmacy teaching. During the nineteenth-century this was the standard promotion at the Faculty of Science, at the Faculty of Medicine and at the Collège de France. Yet, the École was not integrated into the University system in 1808

64 This integration was led by the physician-chemist and dean of the Faculty of Medicine, Mateu Josep Bonaventura (fr. Mathieu) Orfila. Meanwhile, the establishment underwent a "sort of metamorphosis" with the creation in 1834 of two additional chairs (toxicology and elementary physics) which would redefine the use of the premises and introduce a second semester (1st November - 1st April), Louis-René Lecanu, "Rapport sur l'état actuel de l'enseignement dans l'École de pharmacie de Paris," Journal de Pharmacie 22 (1836): 703-14. 
as was the Faculty of Medicine. The École's scientific character was however recognized by the government in the 1840 s when the administration adopted, without making it official, the name of École supérieure de pharmacie. ${ }^{65}$ This recognition was tied to the weight of chemistry in the scientific rise of the establishment. With the exception of Laugier's brief deanship (1829-1832), the three other directors who followed until 1873 were professors of chemistry (Vauquelin, Bouillon-Lagrange, and Bussy).

For these men, chemistry was considered as an "accessory science" (science accessoire) to pharmacy, with a utilitarian value for society and a route to employment opportunities. Some of the brightest students established schools of research specializing in industrial analytical chemistry. These sites cultivated an almost exclusively industrial chemistry, developed side-by-side with the "academic chemistry" developed in 'research schools' led by eminent chemists such as Thenard, Dumas and Pelouze in France, and Thomas Thomson and Justus Liebig abroad. ${ }^{66}$ A pharmacist-chemist like Jean-Baptiste Alphonse Chevallier, who was trained at the École before becoming a professor of pharmacy, was at the head of a laboratory where he trained numerous analysts. ${ }^{67}$ The generalization of such spaces of practical teaching or 'schools of analytical chemistry' significantly contributed to the emergence of the future generations of technicians, expert chemists, and chemical engineers who found numerous career opportunities in the industrial society of the nineteenth and early twentieth-century. These men embodied links between practitioners and scholars and contributed to chemical and sanitary risk management by the development of food science and occupational toxicology where chemistry, politics, justice, and economy were intimately intertwined. ${ }^{68}$

65 The École received the title of Faculty in 1920. Georges Dillemann, "Les établissements d'enseignement pharmaceutique de 1803 à 1994," Annales pharmaceutiques françaises 53 (1995): 1-7.

66 Gerald L. Geison, Frederic L. Holmes, eds., "Research Schools: Historical Reappraisals," Osiris 8 (1993).

67 Alex Berman, "J.B.A. Chevallier, Pharmacist-Chemist: A major figure in nineteenth-century French public health," Bulletin for the History of Medicine $5^{2}$ (1978): 200-13.

68 Soraya Boudia and Nathalie Jas, eds., special issue, "Risk and Risk Society in Historical Perspective," History and Technology 23 (2007). 
PART 3

Revisiting the History of Production 